\title{
Da Cheng Qi Decoction Alleviates Cerulein- Stimulated AR42J Pancreatic Acinar Cell Injury via the JAK2/STAT3 Signalling Pathway
}

\section{Research}

Keywords:

Posted Date: September 22nd, 2020

DOl: https://doi.org/10.21203/rs.3.rs-48121/v2

License: (c) (1) This work is licensed under a Creative Commons Attribution 4.0 International License.

Read Full License 


\section{Abstract}

The authors have requested that this preprint be withdrawn due to author disagreement.

\section{Full Text}

The authors have withdrawn this preprint from Research Square. 